\title{
Pentingnya Komunikasi Receiving Dengan Purchasing Saat Penerimaan Barang Guna Meminimalisir Terjadinya Kesalahan Di Hotel Grand Aston Yogyakarta
}

\author{
Mahyudin ${ }^{1}$, Suradi $^{2}$ \\ Akademi Pariwisata STIPARY Yogyakarta \\ E-mail : mahyudinmandea@yahoo.co.id ${ }^{1}$, suradi_hadi@yahoo.com²
}

\begin{abstract}
The development of tourism industry which increasingly rapidly affect the increasing of hotel industry. This is because the hotel plays a role in supporting the economic sector of tourism. The hotel is one of the accommodation that provides temporary accommodation for tourists who are traveling. In providing a good service, the hotel must have a department or department that works according to their respective responsibilities, whether it is the operational and back office such as Receiving to support the smooth operation of the hotel in terms of receipt of goods. Receiving is one part of the Finance Department which is incorporated in Purchasing which has the duty of responsibility as the main entrance of the goods and is obliged to check the goods first before received from the vendor upon ordering from the Purchasing previously. Receiving is required to receive goods as ordered by Purchasing. (Method used). Data collection techniques in this study using interview techniques, observation, and documentation. Research conducted at the Grand Aston Hotel Yogyakarta for approximately six months. The result of this analysis research is the importance of Receiving communication with Purchasing at receipt of goods to minimize the occurrence of error and maintain the quality standard. In other words Receiving must have a good relationship and cooperation with Purchasing for the smooth operation and also get the results of work as expected.
\end{abstract}

Keywords: Receiving, Purchasing, Hotel, Communication.

Abstrak: Berkembangnya industri pariwisata yang semakin pesat berpengaruh terhadap meningkatnya industri perhotelan. Hal ini karena hotel ikut berperan dalam menunjang sektor ekonomi pariwisata. Hotel adalah salah satu akomodasi yang menyediakan tempat tinggal sementara bagi wisatawan yang sedang melakukan perjalanan wisata. Dalam memberikan pelayanan yang baik, hotel tentunya mempunyai bagian atau department yang bekerja sesuai tugas tanggungjawabnya masingmasing, baik itu bagian operasional maupun back office seperti Receiving untuk menunjang kelancaran operasional hotel dalam hal penerimaan barang. Receiving adalah salah satu bagian dari Finance Department yang tergabung dalam Purchasing yang mempunyai tugas tanggungjawab sebagai pintu utama masuknya barang dan berkewajiban untuk memeriksa barang terlebih dahulu sebelum diterima dari vendor atas pemesanan dari pihak Purchasing sebelumnya. Receiving dituntut untuk menerima barang sesuai yang dipesan oleh Purchasing. ( Metode yang digunakan ). Teknik pengumpulan data yang digunakan dalam penelitian ini menggunakan teknik wawancara, observasi, dan dokumentasi. Penelitian dilakukan di Hotel Grand Aston Yogyakarta selama 3 bulan. Hasil analisa dari penelitian ini adalah Pentingnya komunikasi Receiving dengan Purchasing saat penerimaan barang untuk meminimalisir terjadinya kesalahan serta menjaga standar kualitas. Dengan kata lain Receiving harus mempunyai hubungan serta kerjasama yang baik dengan Purchasing untuk kelancaran kegiatan operasional serta mendapatkan hasil kerja sesuai harapan.

Kata kunci : Receiving, Purchasing, Hotel, Komunikasi.

\subsection{Latar Belakang}

Industri Perhotelan adalah salah satu industri yang berperan penting dalam perkembangan ekonomi dan dunia pariwisata di Indonesia. Seperti yang kita ketahui secara umum hotel adalah seluruh atau sebagian bangunan yang digunakan untuk pelayanan kamar, makanan, dan minuman serta rekreasi yang dikelola dengan tujuan komersial. Sebagai penjual jasa, hotel harus menyediakan berbagai kebutuhan dan fasilitas yang memadai, beserta sumber daya manusia yang terampil dan pengelolaan secara profesional. Maka dari itu hotel sebagai sebuah industri atau perusahaan tentunya mempunyai bagian atau departemen yang bekerja dengan fungsi dan tugas masingmasing, demi untuk kelancaran operasional hotel. Dengan dasar pembahasan tentang bagian penerimaan barang (Receiving) menjadi lingkup pembahasan penulis dalam tugas akhir ini.

Receiving merupakan bagian dari Finance Department yang bertugas sebagai pintu utama masuknya barang dan berkewajiban untuk menerima, memeriksa barang atau bahan olahan yang datang dari pemasok atas pesanan dari bagian pembeliaan( Purchasing ). 
Pada prinsipnya barang-barang yang masuk ke hotel untuk keperluan operasional harus melalui bagian Receiving terlebih dahulu guna sebagai pendataan dan kontrol yang diperlukan. Tujuan utama dari menerima barang-barang adalah untuk mendapatkan barang-barang sesuai standar yang telah ditetapkan oleh pihak hotel, jumlah yang sesuai dengan pesanan serta harga yang tertera dalam list yang telah ditetapkan oleh bagian pembelian (Purchasing ) serta meminimalisir terjadinya kesalahan pada saat penerimaan barang. Dari uraian di atas penulis ingin melakukan penelitian tentang penerimaan barang oleh Receiving dengan judul "Pentingnya Komunikasi Receiving Dengan Purchasing Saat Penerimaan Barang Untuk Meminimalisir Terjadinya Kesalahan Di Hotel Grand Aston Yogyakarta"

\subsection{Tujuan Penelitian}

Adapun tujuan penelitian ini adalah untuk mengetahui pentingnya komunikasi receiving dengan purchasing di Hotel Grand aston Yogyakarta dan untuk mengetahui cara receiving meminimalisir terjadinya kesalahan saat penerimaan barang di Hotel Grand Aston Yogyakarta.

\subsection{Kajian Pustaka}

\subsubsection{Pengertian Hotel}

Definisi Hotel adalah suatu bentuk bangunan, lambang, perusahaan atau badan usaha akomodasi yang menyediakan pelayanan jasa penginapan, penyedia makanan dan minuman serta fasilitas jasa lainnya dimana semua pelayanan itu diperuntukkan bagi masyarakat umum, baik mereka yang bermalam di hotel tersebut ataupun mereka yang hanya menggunakan fasilitas tertentu yang dimiliki hotel itu.

Pengertian hotel ini dapat disimpulkan dari beberapa definisi hotel seperti tersebut di bawah ini :

1. Salah satu jenis akomodasi yang mempergunakan sebagian atau keseluruhan bagian untuk jasa pelayanan penginapan, penyedia makanan dan minuman serta jasa lainnya bagi masyarakat umum yang dikelola secara komersil (Keputusan Menteri Parpostel no Km 94/HK103/MPPT 1987).

2. Bangunan yang dikelola secara komersil dengan memberikan fasilitas penginapan untuk masyarakat umum dengan fasilitas sebagai berikut :

a. Jasa penginapan

b. Pelayanan makanan dan minuman

c. Pelayanan barang bawaan

d. Pencucian pakaian e. Penggunaan fasilitas perabot dan hiasan-hiasan yang ada di dalamnya (Endar Sri, 1996:8).

3. Sarana tempat tinggal umum untuk wisatawan dengan memberikan pelayanan jasa kamar, penyedia makanan dan minuman serta akomodasi dengan syarat pembayaran (Lawson, 1976:27)

\subsubsection{Karakteristik Hotel}

Perbedaan antara hotel dengan industri lainnya adalah :

1. Industri hotel tergolong industri yang padat modal serta padat karya yang artinya dalam pengelolaannya memerlukan modal usaha yang besar dengan tenaga pekerja yang banyak pula.

2. Dipengaruhi oleh keadaan dan perubahan yang terjadi pada sektor ekonomi, politik, sosial, budaya, dan keamanan dimana hotel tersebut berada.

3. Menghasilkan dan memasarkan produknya bersamaan dengan tempat dimana jasa pelayanannya dihasilkan.

4. Beroperasi selama 24 jam sehari, tanpa adanya hari libur dalam pelayanan jasa terhadap pelanggan hotel dan masyarakat pada umumnya.

5. Memperlakukan pelanggan seperti raja selain juga memperlakukan pelanggan sebagai patner dalam usaha karena jasa pelayanan hotel sangat tergantung pada banyaknya pelanggan yang menggunakan fasilitas hotel tersebut.(http://www.mandalabhakti.ac.id/n ews_1_Pengantar-Perhotelan--DefinisiHotel-Karakteristik-Jenis-dan-KlasifikasiHotel-.htmldiunduh tanggal 07 November 2016).

\subsubsection{Pengertian Penting}

Berdasar pada Kamus Besar Bahasa Indonesia pengertian kata penting memiliki arti

1. Pokok, utama

2. Sangat berharga ( berguna)

3. Mempunyai posisi yang menentukan

Kata dasar penting disini jika ditambahkan dengan awalan dan akhiran memiliki beberapa kata dengan arti yang berbeda.

1. Mementingkan, artinya :
a. Lebih menentukan
b. Mendahulukan

2. Terpenting, artnya :

a. Paling utama

b. Paling perlu

Untuk itu dapat diartikan bahwa kata "Pentingnya" adalah suatu pokok yang utama. (http://kbbi.web.id/penting diunduh tanggal 07 November 2016). 


\subsubsection{Pengertian Komunikasi}

Komunikasi merupakan tindakan melaksanakan kontak antara pengirim dan penerima, dengan bantuan pesan dan penerima memiliki beberapa pengalaman bersama yang memberi arti pada pesan dan simbol yang dikirim oleh pengirim dan diterima serta ditafsirkan oleh penerima. (http://www.defenisi-

pengertian.com/2015/08/pengertian-

komunikasi-defenisi-menurut-ahli.html diunduh tanggal 07 November 2016 )

Pada hakekatnya hotel sebagai tempat berkumpulnya orang-orang atau sebagai tempat melakukan komunikasi. Semua fungsi dalam organisasi modern tergantung pada komunikasi seperti dalam situasi hotel, setiap orang yang berperan didalamnya memerlukan komunikasi. Mulai dari Manager sampai pelaksana pada hotel tersebut perlu mengenal alur komunikasi yang ada, baik secara horizontal, veertikal maupun diagonal.

Jika pesan yang disampaikan itu dapat dipahami orang lain maka dapat dikatakan bahwa komunikasi itu berhasil jika sebaliknya berarti gagal. Seorang komunikator yang efektif harus mampu memberikan pengertian dan ide-ide secara terampil. Dan pegawai hotelpun perlu memehami komunikasi agar dapat tercipta komunikasi yang sehat terbuka. Sehingga hasil dari komunikasai yang berjalan baik tersebut, antara lain :

1. Meningkatkan loyalitas antar sesama personal yang ada di dunia hotel.

2. Meningkatkan gairah kerja pegawai.

3. Meningkatkan disiplin yang tinggi

4. Meningkatkan kerjasama antar karyawan

5. Meningkatkan rasa tanggung jawab

6. Mempercepat informasi yang dibutuhkan satu sama lain

7. Meningkatkan operasional yang efisien (http://akomodasi-

perhotelan.blogspot.co.id/2014/02/

komunikasi-dalam-industri-perhotelan.html diundih tanggal 07 November 2016 ).

\subsubsection{Pengertian Receiving}

Receiving merupakan salah satu bagian dari Finance Department yang bertanggungjawab terhadap penerimaan barang di hotel. Receiving juga disebut sebagai pintu utama masuknya barang barang yang di order untuk kebutuhan perusahaan, maka dari itu receiving merupakan bagian penting dalam proses penerimaan semua barang masuk untuk hal itu yang harus diperhatikan adalah quantity, kualitas serta nominal harga barang yang harus sesuai dengan Purchase Order atau Market List.
Menurut Bartono (2005 : 70) staff Receiving berkewajiban untuk menerima, memeriksa barang, atau bahan olahan yang datang dan diserahkan oleh pemasok atas pesanan dari bagian pembelian. Pada prinsipnya semua barang-barang yang masuk ke hotel untuk keperluan operation harus melalui bagian receiving,guna pendataan dan kontrol yang diperlukan. Adapun tujuan utama dari menerima barang-barang adalah mendapatkan barang-barang yang berkualitas dan jumlah yang sesuai dengan pesanan dan sesuai dengan harga yang dicatat.

Selain menerima, receiving juga harus mengadakan pengawasan dan ketelitian di saat barang-barang tersebut datang dan diserahkan oleh pemasok. Menurut Endar Sugiarto, dkk (1997: 5) bahwa "Pengawasan pada hakikatnya merupakan usaha memberikan petunjuk kepada para pelaksana agar mereka selalu bertindak sesuai dengan rencana".

Petugas receiving diharapkan mampu membatasi tindakan-tindakannya dalam mencapai tujuan sehingga tidak menyimpang dari rencana, dan akan berjalan pada garisnya bila ada aturan yang jelas dan dipercaya. Dalam pengawasan juga diperlukan ketelitian dimana pengawasan merupakan kegiatan yang berhubungan dengan sistem-sistem pengontrolan, yang dapat digambarkan sebagai suatu proses perencanaan perbaikanperbaikan yang tidak ada hentinya, maka ketelitian sangat diperlukan. Fungsi receiving: memeriksa kuantitas, kualitas, harga,dan delivery barang yang datang dari supplier ke hotel dan menyesuaikannya dengan Purchase $\operatorname{Order}(\mathrm{PO})$ yang telah dibuat oleh department purchasing.

Standar Operasional dari seorang receiving adalah menerima dan mengecek barang sesuai prosedur dan selanjutnya barang yang diterima diserahkan kepada Store keeper atau outlet / departemen dari yang memesan barang tersebut.

Peranan receiving adalah sebagai petugas penerimaan barang, antara lain:

1. Menerima dan mencocokkan semua barang-barang yang datang di hotel sesuai dengan order dan didukung oleh Purchase Order atau Market List.

2. Menulis receiving report untuk semua barang-barang yang datang di hotel dan memindahkan ke Daily Receiving Sheet yang didistribusikan ke Cost Control.

3. Memberitahukan kepada Storekeepers dan Departemen terkait untuk barangbarang yang datang, sebab barang-barang tersebut harus dipindahkan dari area Receiving Clerk. 
4. Memberikan cap pada faktur dengan Cap receiving report dan tanda tangan bila telah diterima.

5. Apabila barang yang datang tidak memenuhi ketentuan standar, dicatat dalam "Memorandum Invoice" dan segera diberitahukan kepada purchasing, dan nantinya purchasing akan memberitahu kepada vendor.

(Sumber:http://www.stpsahidsolo.ac.id/ind ex.php?id=artikel\&kode $=7$; http://cinkeynaa ra.blogspot.com/2011/11/prosedur.peneri maan-barang-di-receiving.htm;

https://harianakuntansi.wordpress.com/201 5/02/05/receiving-hotel/diunduh tanggal 07 November 2016).

\subsubsection{Pengertian Purchasing}

Menurut Assauri (2008 : 223) Pembelian merupakan salah satu fungsi yang penting dalam berhasilnya operasi suatu perusahaan. Fungsi ini dibebani tanggung jawab untuk mendapatkan kuantitas dan kualitas bahanbahan yang tersedia pada waktu dibutuhkan dengan harga yang sesuai dengan harga yang berlaku. Pengawasan perlu dilakukan terhadap pelaksanaan fungsi ini, karena pembelian menyangkut investasi dana dalam persediaan dan kelancaran arus bahan ke dalam pabrik. Sedangkan menurut Mulyadi (2007 : 711) aktivitas dalam proses pembelian barang adalah:

1. Permintaan pembelian

2. Pemilihan pemasok

3. Penempatan order pembelian

4. Penerimaan barang, dan

5. Pencatatan transaksi pembelian

Permintaan pembelian adalah contoh suatu aktivitas yang merupakan satuan pekerjaan yang ditujukan untuk memicu bagian pembelian melakukan pengadaan barang sesuai dengan spesifikasi dan jadwal sebagaimana yang dibutuhkan oleh pemakai barang. Penerimaan barang adalah contoh aktivitas tentang penerimaan kiriman dari pemasok sebagai akibat adanya order pembelian yang dibuat oleh bagian pembelian.

Beberapa pengertian tentang pembelian (Purchasing):

1. Purchasing adalah kegiatan pengadaan barang atau jasa untuk mencapai tujuan organisasi atau perusahaan. Tujuan utama dari purchasing department adalah untuk menjaga kualitas dan nilai dari produk perusahaan, meminimalisasikan perputaran modal yang dipakai untuk penyediaan stok barang, menjaga aliran barang masuk dan barang keluar, dan memperkuat daya saing organisasi atau perusahaan. Purchasing juga bisa dikatakan dalam penerimaan dan pemrosesan permintaan resmi (proses pembelian barang), membuat penawaran dan mencari barang, evaluasi penawaran, pemeriksaan atas barang yang diterima dan mengawasi atas penyimpanan dan pemakaian yang tepat.

2. Purchasing dapat diartikan sebagai usaha untuk memenuhi kebutuhan atas barang atau jasa yang diperlukan oleh perusahaan dan dapat diterima tepat pada waktunya dengan mutu yang sesuai serta harga yang menguntungkan.

3. Purchasing adalah salah satu fungsi utama diantara fungsi-fungsi penting lainnya yang ada didalam suatu perusahaan atau perhotelan, seperti: administrasi, pembukuan, penjualan dan pemasaran. Pembelian telah banyak didefinisikan oleh para ahli dengan meninjau sudut pandang yang berbeda namun pada dasarnya memiliki pengertian yang sama.

Dari pengertian di atas, maka dapat disimpulkan bahwa purchasing atau pembelian adalah suatu usaha dalam memenuhi kebutuhan atas barang dan jasa yang diperlukan oleh perusahaan dengan melihat kualitas atau mutu, kuantitas dari barang yang dikirim, serta harga dan waktu pengiriman yang tepat. (Sumber http://arripple.blogspot.co.id/2016/04/pengertia n-purchasing-menurut-para-ahl.html diunduh tanggal 11 Januari 2017).

\subsubsection{Pengertian Penerimaan Barang}

Penerimaan Barang adalah "Menerima fisik barang dari pabrik, prinsipal atau distributor yang disesuaikan dengan dokumen pemesanan dan pengiriman dan dalam kondisi yang sesuai dengan persyaratan penanganan barangnya". Didalam aktifitas penerimaan barang ini terdapat 3 point penting yang tidak dapat dipisahkan satu dengan lainnya:

1. Fisik barang yang diterima

2. Dokumen Di Receiving

3. Cara penanganan barang

a. Fisik Barang Yang Diterima

Adalah bentuk fisik barang yang harus dapat dirasa, diraba atau dilihat langsung. Penerimaan yang bukan berupa fisik barang dapat menyebabkan perbedaan proses dan hasil yang akan dicapai. Pada umumnya hasilnya adalah negatif. Jika ada penerimaan tanpa harus menangani fisik barangnya, maka perlu dilakukan proses tambahan untuk memastikan keabsahan proses tsb. Prinsip penerimaan barang adalah menerima fisik barang secara langsung. Bukan hanya dokumen saja. 
Secara fisik, barang dapat dilihat, diraba atau dirasa dan dapat dibandingkan dengan dokumen pengantaran.

1) Pengecekan acak atau keseluruhan kondisi isi kemasan

2) Tanggal Kadaluarsa barang, nomor batch

3) Kuantitas barang VS dokumen (Sumber

http://logistikindonesia.blogspot.co.id/2 010/07/penerimaan-barang.html

diunduh tanggal 07 November 2016 ).

b. Dokumen Di Receiving

Dokumen pemesanan barang diterima berdasarkan adanya dokumen yang mendasari berapa barang yang harus diterima, jenis barangnya apa dan untuk memastikan bahwa barang yang diterima adalah sama dengan barang yang dikirimkan. Dokumen adalah pendamping barang yang secara fisik dapat dibaca dan dicocokan dengan barang yang dikirimkan.Dokumen yang diperlukan minimal:

1) Surat Jalan, adalah dokumen yang berfungsi sebagai surat pengantar atas barang yang tercantum didalamnya yang ditunjukan kepada pembeli dengan tercantum jumlah barang dan spesifikasi barang yang dikirimkan.

(Sumber

http://zulidamel.wordpress.com/200 $8 / 01 / 25 /$ delivery-order-order-suratjalan/diunduh tanggal 02 Januari 2017 ).

2) Invoice, adalah suatu bukti catatan yang berisi nama barang yang dikirim kepada pembeli beserta harga dan total hutang yang harus dibayar oleh pembeli.

(Sumber

http://defenisibuku.blogspot.co.id/2 016/05/pengertian-

invoice. $h t m l ? m=1$ diuduh tanggal 02 Januari 2016). Dan akan lebih baik jika dilampirkan copy PO nya juga.

c. Cara Penanganan Barang

Persyaratan penanganan; kondisi khusus yang harus disiapkan pada saat barang tsb diterima. Apakah perlu ditangani pada suhu/temperatur khusus atau perlu dilakukan penanganan khusus dikarenakan faktor beratnya, tingkat kesulitannya atau masalah lainnya. Tangani barang sesuai dengan siklus hidupnya

1) Suhu

2) Kadaluarsa
3) Maksimal tumpukan gunakan peralatan yang sesuai

Secara umum dapat dinyatakan bahwa penerimaan barang merupakan aktifitas operasional gudang yang sangat penting karena merupakan awal dari penanganan barang.Logika umum mengatakan bahwa penerimaan barang yang baik saja masih memungkinkan terjadinya kerusakan/kesalahan barang didalam gudang, terlebih jika pada saat penerimaan barang ditangani dengan cara yang tidak benar, dijamin kerusakan/kesalahan tsb pasti terjadi. (Sumber:

http://logistikindonesia.blogspot.co.id/2010/07/ penerimaan-barang.html diunduh tanggal 07 November 2016).

\subsection{Metode Penelitian}

Penelitian ini bersifat deskriptif kualitatif dengan mengambil bentuk studi kasus. Juga dikemukakan juga orientasi teoritis, yaitu landasan berfikir untuk memahami makna suatu gejala. (Dwiloka \& Riana, 2005 : 77). Pendekatan penelitian yang digunakan dalam penelitian ini adalah pendekatan kualitatif deskriptif. Artinya data dikumpulkan beberapa kata-kata, gambar dan bukan angka (Moleong, 2001:6). Sedangkan tehnik Pengumpulan data yang digunakan :

1. Observasi Langsung

Pengumpulan data dengan observasi langsung adalah cara pengambilan data dengan cara menggunakan mata tanpa ada pertolongan penggunaan alat standar lain untuk keperluan tersebut, dengan melakukan pengataman secara langsung ini maka penulis akan memperoleh data yang diperlukan dalam penulisan ini.

2. Wawancara

Pengumpulan data dengan cara ini dilakukan dengan cara memperoleh dan secara langsung dari responden yaitu dengan bercakap-cakap secara bertatap muka. Pada penelitian ini wawancara dilakukan dengan Senior Cook.

3. Kepustakaan

Pengumpulan data secara kepustakaan diperoleh dengan menggunakan buku atau bahan lain yang dapat digunakan sebagai data pustaka penulisan laporan penelitian. Dengan kepustakaan ini maka akan memperkuat penulisan laporan.

4. Dokumentasi

Pengumpulan data dengan cara mengambil gambar atau foto yang diperoleh dalam arsip hotel. 


\subsection{Hasil Penelitian Dan Pembahasan}

4.1.1. Sejarah dan Latar Belakang Grand Aston Hotel Yogyakarta

Grand Aston Yogyakarta Hotel \& Convention Center merupakan Hotel \& Convention Center Internasional bintang ***** (5), terletak di Jalan Urip Sumoharjo yang biasa disebut juga dengan Jalan Solo oleh masyarakat lokal, berdekatan dengan Mall Galleria yang terkenal tepat di pusat perbankan dan perkantoran Yogyakarta dan berdekatan dengan Jalan Malioboro yang legendaris. Hotel Grand Aston Yogyakarta berdiri pada tahun 2011 yang berada dibawah naungan Archipelago International Group. Hotel ini menawarkan 141 kamar dan 3 kamar suite yang bertemakan desain javanesse, Cinnoseries, dan Western serta 1 kamar Presidental Suite dengan tema Majapahit. Untuk restoran terdapat SaffronRestaurant, dan Cassia Lobby Lounge yang berada di Ground Floor, kemudian ada Cinamoon Poolbar yang berada di lantai dua tepatnya didekat pool, dan kemudian ada Sky Dinning terbuka yang bernama Vanilla Sky Lounge.

Grand Aston Hotel Yogyakarta \& Convention Center merupakan Grand Aston Hotel kedua di Indonesia dan dipersiapkan untuk mengikuti kesuksesan Grand Aston sebelumnya yaitu, Grand Aston City Hall di Medan. Hotel ini telah dikonsepsualisasikan untuk menjadi hotel yang lain dari pada yang lain, modern dan bergaya sehingga membawa nuansa baru bagi Yogyakarta.

\subsubsection{Struktur Organisasi Purchasing Section}

Pada dasarnya Finance Department mempunyai tanggungjawab yang besar karena Finance Department lah yang mengontrol, menganalisa, mengawasi, mencatat, merekap dan menyetujui atas semua permintaan pembelian barang setiap department, dan setiap akhir bulan akan diadakan Inventory untuk memastikan semua sesuai dengan bukti yang ada. Nantinya akan dibuat laporan dan diserahkan kepada General Manager dan dapat dipertanggungjawabkan dengan bukti pendukung yang akurat.

1. Pengertian Section

Grand Aston Hotel Yogyakarta mempunyai fasilitas yang lengakap serta didukung dengan beberapa department untuk mempelancar kegiatan sehari-hari antara lain yaitu Finance Department.

Finance Department di Grand Aston Hotel Yogyakarta memiliki 2 section, yaitu:
a. Accounting
b. Purchasing

2. Struktur Organisasi Purchasing Section

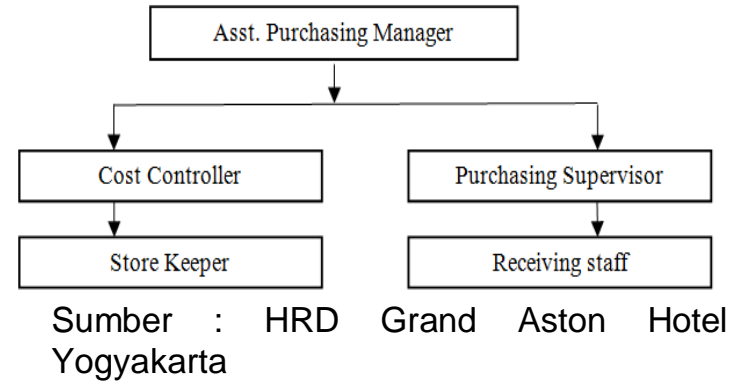

Gambar 1. Struktur Organisasi Purchasing Section Grand Aston Hotel Yogyakarta

3. Job Description

a. Asst. Purchasing Manager

1) Membantu atau menggantikan purchasing manager bila tidak berada di tempat.

2) Membuat laporan keuangan ( Neraca, $R / L$ ) untuk disahkan oleh Fin. Adm. Manager.

3) Mengawasi pekerjaan purchasing supervisor.

4) Bertanggung jawab langsung kepada purchasing manager.

b. Purchasing Supervisor

1) Menerima dan mereview surat permintaan barang dari seluruh bagian baik yang harian maupun yang bulanan

2) Melakukan pemeriksaan terhadap ketepatan pemeriksaan dengan anggaran dan atau kebutuhan

3) Melakukan pendataan terhadap supplier dari segi harga, kesiapan dan ketepatan pengiriman serta kualitas barang yang mereka tawarkan sebagai data untuk melakukan seleksi supplier.

4) Melakukan proses pembelian dari mulai permohonan, penawaran harga, penyiapan kelengkapan administrasi sampai kepada pengontrolan ketepatan pembelian.

5) Menyiapkan pembayaran melalui kas kecil lainnya dan pendataan pengeluaran tersebut.

6) Melakukan review dan rekap pembelian per bulan dan analisa ketepatan berdasarkan anggaran.

7) Berkoordinasi dengan bagian lain untuk kesesuaian spesifikasi barang dan waktu pengiriman.

8) Menjalankan tugas-tugas terkait lainnya dalam permasalahan administrasi kasir.

\subsection{Pembahasanan}

4.2.1. Pentingnya Komunikasi Receiving Dengan Purchasing Di Hotel Grand Aston Yogyakarta 
Komunikasi merupakam rutinitas yang wajib dilakukan oleh siapa saja dan dimana saja apalagi dalam lingkungan kerja. Komunikasi adalah akses dimana seseorang dapat menyampaikan pesannya kepada lawan bicaranya. Dengan terjalinnya komunikasi yang baik akan mempermudahkan pekerjaan satu sama lain. Dengan kata lain komunikasi adalah hal pokok berhasil atau tidaknya suatu pekerjaan. Berikut contoh komunikasi yang terjalin antara receving dengan purchasing.

1. Purchasing mendapat permintaan pembeliaan barang dari department lain, dan setelah purchasing memesankan barang tersebut kepada vendor makapurchasing akan memberikan daily market list atau purchase order kepada receiving sebagai dasar penerimaan barang nantinya.

2. Receiving berhak memeriksa daily market list dan purchase order, karena apabila ada sesuatu yang belum jelas dapat ditanyakan langsung kepada purchasing sebelum barang itu datang dan diterima.

3. Dalam pelaksanaanya receiving juga melakukan komunikasi dengan department lain, dalam hal ini adalah department yang memesan barang tersebut. Contoh komunikasi receiving dengan department lain.

Receiving dengan food \& beverage product department yaitu receiving akan memberitahukan kepada chef atas kedatangan unggas, dan meminta tolong kepada chef untuk memeriksanya.

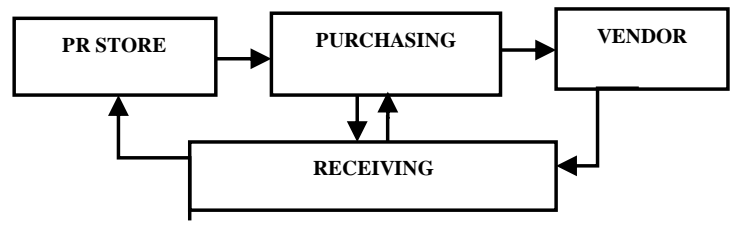

Sumber : SOP Receiving Grand Aston Hotel Yogyakarta

\section{Gambar 2. Flow Of Goods Using Purchase Order (Food)}

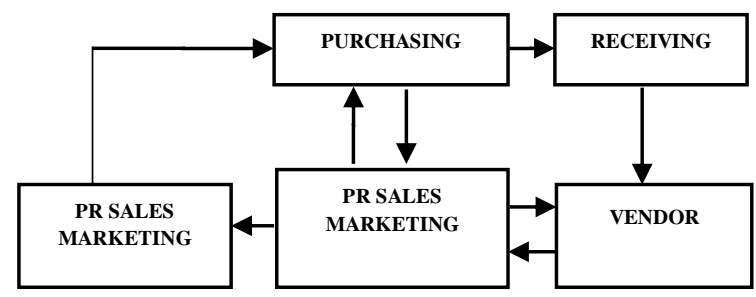

Sumber : SOP Receiving Grand Aston Hotel Yogyakarta

\section{Gambar 3. Flow Of Goods Using Purchase Order (Material/ Backdrop)}

Bentuk komunikasi yang berjalan pada receiving Grand Aston Hotel Yogyakarta yaitu :

1. Komunikasi ke atas

Adalah komunikasi dari receiving kepada purchasing supervisor atau asst. Purchasing manager.

2. Komunikasi kebawah

Adalah komunikasi dari atasan ( purchasing supervisor atau asst. Purchasing manager) kepada bawahannya ( receiving)

3. Komunikasi horizontal

Adalah komunkasi antara receiving dengan department lain.

4. Komunikasi Kompleks

Adalah komunikasi antara receiving dengan vendor

Dalam pelaksanaan kerja receiving menjumpai pembelian barang secara tunai (cash). Pembelian barang secara tunai disebabkan karena kebutuhan yang mendadak pada hari itu juga, sehingga dibelikan saat itu juga secara tunai. Pembelian yang dilakukan secara tunai tentunya atas sepengetahuan dan persetujuan dari purchasing.

Pembelian barang secara tunai oleh purchasing akan menggunakan uang house bank. House bank yaitu uang tunai yang digunakan untuk keperluan operasional pembelian secara tunai yang disediakan oleh hotel tetapi tidak dalam jumlah yang banyak. Sedangkan jika barang tersebut dibeli oleh department terkait, terlebih dahulu menggunakan uang pribadi yang nantinya akan diganti oleh general cashier.

Pada dasarnya perlakuan pembelian secara tunai juga sama seperti barang yang dibeli secara kredit yaitu barang yang telah dibeli harus diperlihatkan kepada receiving sebagai bukti bahwa barang tersebut memang benar dibeli. Nantinya baik dibeli oleh purchasing atau department terkait nota dari pembelian barang tersebut harus dilampiri dengan lembar cash advance yang telah di tandatangani oleh department head dan financial controller terlebih dahulu agar dapat di input oleh receiving sebagai cash purcahse report. Untuk barang yang dibeli oleh department terkait uang tersebut dapat langsung diganti oleh general chasier dengan disertai cash purchase report. Sedangkan jika dibeli oleh purchasing akan disimpan oleh purchasing sendiri yang nantinya pada akhir bulan akan diperiksa oleh account receivable sebagai bukti telah terjadi pengeluaran uang untuk pembelian barang secara tunai.

Sedangkan untuk barang tipe parsial (tidak datang sekaligus dalam 1 kali pengiriman) dan purchase order telah diterima receiving, maka akan tetap di input barang tersebut kedalam sistem dan mencatat pada 
purchase order dengan cara membuat kolom balance sesuai barang yang diterima, hal ini juga dapat dijadikan sebagai contoh jumlah barang yang diterima dan yang belum diterima. Biasanya barang yang parsial ini dipesan oleh bagian store untuk mengisi persediaan yang hampir habis. Sebagai contoh untuk barang materialnya adalah sandal tamu pada kamar, purchase request yang dibuat oleh store adalah memesan barang tersebut sebanyak 10000 pasang dalam satu purchase order. Sandal tersebut akan didatangkan sebanyak 5 kali dalam satu purchase order (satu kali datang 2000 pasang). Contoh lain dari barang material adalah beras. Store membuat purchase request dengan memesan besar sebanyak $300 \mathrm{~kg}$ dalam satu purchase order dan akan ditangkan sebanyak dua kali dalam satu purchase order ( satu kali datang $150 \mathrm{~kg}$ ). Alasan barang ditangkan secara parsial adalah karena kapasitas tempat gudang yang tidak mencukupi untuk buffer stock dan bisa juga dari permintaan vendor karena proses pembuatan yang cukup lama atau persediaan yang kurang mencukupi untuk didatangkan dalam satu kali. Selain alasan tersebut kedatangan barang secara parsial juga dapat berpengaruh pada biaya. Nantinya biaya yang dibebankan akan menyesuaikan dari jumlah kedatangan barang pada tiap bulannya.

Menurut Ibu Heny Purwaningsih sebagai Receiving Staff tentang Bagaimana Pentingnya Komunikasi Receiving dengan Purchasing di Grand Aston Hotel Yogyakata? "komunikasi sangatlah penting, komunikasi menjadi media penyambung antara receiving dengan purchasing. Setiap hari receiving akan selalu berkomunikasi dengan purchasing karena purchasing lah yang berhubungan langsung dengan supplier atau vendor atas pemesanan barang sebelumnya. Purchasing yang lebih mengetahui tentang spesifikasi barang yang dipesan sebelumnya kepada vendor.Dengan terjalinnya komunikasi yang baik akan memperlancar pekerjaan kedua pihak yaitu purchasing dan receiving." ( Heny Purwaningsih, Receiving Staff)

Permasalahan komunikasi yang dialami antara receiving dengan purchasing dan upaya penyelesaiannya. Receiving sering mengalami permasalahan komunikasi dengan purchasing yaitu berupa kedatangan barang yang telah dipesan tetapi belum ada purchase order dan tidak ada informasi sebelumnya. Seperti yang telah diuraikan sebelumnya purchase order adalah hal pokok yang dijadikan sebagai dasar penerimaan barang oleh receiving. Seringkali terjadi penerimaan barang tetapi purchase order belum diterima oleh receivingatau belum jadi. Sebagai contohnya adalah kedatangan alat tulis kerja (ATK). Dimana barang tersebut bukanlah barang yang mendesak untuk didatangkan karena biasanya dipesan jauh hari sebelum digunakan oleh department terkait, akan tetapi reveiving belum menerima purchase order. Hal ini dapat meghambat pekerjaan receiving.

Oleh karena itu receiving akan segera menginformasikan kepada purchasing atas kedatangan alat tulis kerja tersebut apakah benar memesan atau tidak, jika benar memesan seperti apa spesifikasinya, berapa jenis, jumlah dan harga barang tersebut serta department mana yang memesan. Dalam hal ini receiving mengharapkan kerjasama dengan purchasing agar bekerja sesuai dengan standar operasional prosedur yang telah ditetapkan oleh management sehingga mempermudah pekerjaan satu sama lain.

Pemesanan barang yang dilakukan sebelum diterbitkannya purchase order biasanya adalah barang yang benar-benar mendesak (urgent), yang harus didatangkan secepat mungkin. Hal ini tentunya sudah mendapat persetujuan dari financial controller dan telah dipertimbangkan sebelumnya. Contohnya yaitu berupa pemesanan kran air yang rusak pada kamar tamu, jika tidak diperbaiki sesegera mungkin tentunya kamar tersebut tidak bisa dijual kepada tamu dan akan menyebabkan kerugian yang cukup besar. Maka dari itu barang akan segera didatangkan meski purchase order belum jadi untuk menghidari terjadinya kerugian akibat kerusakan kran pada kamar tamu. Setelah barang tersebut datang purchasing harus segera memproses purchase request (pr) menjadi purchase order agar bisa diinput oleh receiving.

Dari analisa diatas, penulis menganalisa bahwa kurangnya komunikasi yang baik antara receiving dengan purchasing adalah kendala dalam melaksanakan pekerjaan sehari-hari. Kurangnya komunikasi yang baik dapat menghambat pekerjaan satu sama lain dan berpengaruh terhadap hasil yang didapatkan. Selain komunikasi menurut penulispurchasingbelum sepenuhnya bekerja sesuai dengan standar operasional prosedur yang telah ditetapkan.

Menurut analisa penulis, untuk mengatasi kendala tersebut perlu ditingatkan team work atau kerjasama yang baik antara receiving dengan purchasing. Kendala yang dirasakan oleh receiving maupun purchasing dapat disampaikan pada saat morning breafing. Baik receiving maupun purchasing harus mampu menyampaikan kendala tersebut. Hal ini akan dijadikan sebagai koreksi atau evaluasi untuk memperbaiki kendala 
tersebut agar tidak terulangterus menerus. Menurut penulis purchasing harus mampu bekerja sesuai dengan standar operasional prosedur yang telah ditetapkan serta mampu menjalin komunikasi yang baaik dengan receiving. Dengan terjalin komunikasi yang baik dan bekerja sesuai dengan standar yang ditetapkan sangat berpengaruh dengan hasil kerja yang didapatkan.

\subsubsection{Cara Receiving Untuk Meminimalisir} Terjadinya Kesalahan Pada Saat Penerimaan Barang Di Hotel Grand Aston Yogyakarta

Receiving dapat dikatakan sebagai pintu utama keluar masuknya barang di hotel. Receiving mempunyai tugas menerima dan menolak barang yang telah dipesan pihak purchasing sebelumnya jika tidak sesuai dengan pesanan. Sebelum barang diterima receiving wajib mengecek terlebihdahulu untuk memastikan bahwa barang yang diterima sudah sesuai pesanan.

Sebelum melaksankan tugas dalam penerimaan barang receiving diberi Daily Market List atau Purchase Order (PO) oleh pihak purchasing yang nantinya akan digunakan sebagai dasar penerimaan barang. Daily Market List berisi no artikel barang pada sistem, nama barang yang dipesan (sudah dipisahkan sesuai dengan jenisnya masingmasing), jumlah yang dipesan, harga,nama supplier, jumlah harga peritem. Sedangkan Purchase Order berisi nama supplier, tanggal order, nomer PO, nomer PR, departmentyang memesan, nama barang, jumlah yang dipesan, unit, harga per unit, jumlah harga per unit, dan total harga keseluruhan.

Untuk daily market list sebelum diserahkan ke receiving tentunya sudah mendapat tandatangan sebagai bukti telah disetujui baik dari department head, Cost control, Financial Controller, dan purchasing, sedangkan untuk Purchase Order sudah tercantum tandatangan purchasing, general manager, dan financial controller.

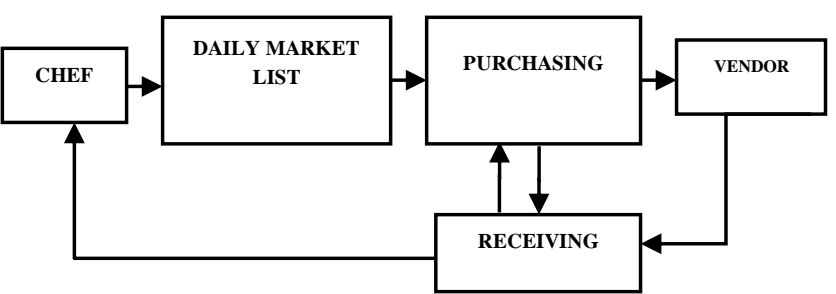

Sumber : SOP Receiving Grand Aston Hotel Yogyakarta

$$
\begin{gathered}
\text { Gambar 4. Flow Of Goods Using Daily Market } \\
\text { List }
\end{gathered}
$$

Berikut merupakan penjelasan dari gambar diatas mengenai prosedur penerimaan barang oleh receiving untuk meminmalisir terjadinya kesalahan saat penerimaan barang.

1. Menerima dan memeriksa lembar pesanan dari purchasing sebagai dasar penerimaan barang. Hal ini untuk memastikan bahwa semua daftar telah benar dan apabila ada yang kurang jelas bisa segara ditanyakan ke purchasing.

2. Menerima barang yang datang dari suppiler atas dasar pesanan dan memeriksanya terlebihdahulu baik jenis, jumlah, kualitas, tanggal kadaluarasa, dan harga apakah sudah sesuai atau belum. Jika terjadi perbedaan segera konfirmasi purchasing untuk memastikan agar tidak terjadi kesalahan.

3. Menginformasikan kepada chef atas kedatangan jenis daging,unggas ataupun makanan laut yang perlu dibantu untuk mengeceknya dan memastikan bahwa yang datang layak untuk diterima atas persetujuan chef.

4. Untuk sayuran yang datang dan telah dicek dan ditimbang akan dicuci oleh supplier dan meletakannya pada keranjang yang telah disedikan dan memasukkannya kedalam chiler yang nantinya akan ditata oleh orang kitchen.

5. Menerima invoice atau nota dari supplier untuk ditandatangani dan diberi stempel pihak receiving staff. Invoice asli untuk receiving dan copy untuk pihak supplier sedangkan untuk tanda terima receiving hanya mendapatkan slip copy dan yang asli untuk pihak supplier ( kebalikan dari invoice). Baik invoice atau tanda terima keduanya harus diperiksa terlebihdahulu untuk memastikan yang tercantum dan yang diterima semua sama dan sesuai, nantinya akan dilampirkan pada saat pembuatan laporan.

6. Jika pada saat pengiriman barang supplier tidak membawa invoice atau tanda terima, maka receiving akan membuatkan dua tanda terima yang diberi stempel dan tanda tangan kedua pihak ( satu untuk supplier dan satunya untuk disimpan receiving ) yang nantinya akan segera digantikan invoice yang asli keesokan harinya.

7. Setelah barang diterima receiving akan menginformasikan kepada department yang memesan agar segera diambil supaya tidak berserakan.

8. Receiving akan kembali mengecek daftar barang yang telah dipesan dan apabila masih ada yang belum datang akan segera membuat daftar outstanding order dan memberikan kepada purchasing dan juga 
menginformasikan kepada chef atau secretarisnya barang yang belum datang.

9. Semua barang yang telah diterima hari itu juga harus dipostingkedalam sistem (VHP) berdasarkan daily market list atau $P O$ sesuai department yang memesan kemudian dicetak dan dilampirkan dengan invoice sebagai bukti penerimaan barang yang kemudian dikirimkan ke masingmasing department yang tercantum untuk dimintai tandatangan tiap departmenthead dan keesokan harinya akan ditarik kembali untuk diserahkan kepada cost control untuk di cek dan di tandatangani. Setelah selesai di cek oleh cost control akan dikembalikan kepada receiving untuk dibuatkan jurnal untuk memastikan bahwa antara debit dan kredit sama, lalu diserahkan kepada chief accountan untuk dicek dan di tandatangani, selanjutnya chiefaccountan akan memberikannya kepada account payable untuk masalah pembayaran.

Menurut lbu Heny Purwaningsih sebagai receiving staff tentang Bagaimana Cara Receiving Meminimalisir Terjadinya Kesalahan pada saat Penerimaan Barang? "Pada dasarnya receiving sebagai penerima barang harus selalu mengecek barang yang datang seteliti dan sedetail mungkin, memahami spesifikasi barang yang diterima mulai dari merk, kondisi barang, maupun tanggal kadaluarsa.Receiving juga perlu menjalin komunikasi dengan departmentlain yaitu yang memakai, saat barang yang dipesan datang bila perlu department yang bersangkutan ikut mengeceknya secara langsung. Selain dengan department yang memakai komunikasi yang terpenting adalah antara receiving dengan purchasing, karena purchasing lah yang bersangkutan langsung dengan supllier atas barang yang dipesan sebelumnya dan dengan department yang memesan atau memakai barang tersebut."(Heny Purwaningsih, Receiving Staff).

Setiap akhir bulan purchasing akan memberikan daftar sayuran dan buah kepada tiap vendor untuk mengisi harga jual yang ditawarkan kepada hotel yang akan diberlakukan selama satu bulan kedepan. Daftar tersebut dapat diartikan sebagai harga kontrak selama satu bulan kedepannya. Daftar tersebut harus dikembalikan dalam waktu maksimal tiga hari karena nantinya purchasing akan memilih harga terendah dari tiap vendor dengan mempertimbangkan kualitas agar tetap terjaga..Akan tetapi disini tidak semua vendor mendapat daftar tersebut, hanya untuk vendor buah dan sayur, sedangkan yang lian tidak. Hal ini karena harga barang tersebut tidak bisa digunakan dalam jangka waktu yang cukup lama, bahkan bisa terjadi perubahan dalam waktu dua hari sekali.

Permasalahan yang dihadapi oleh receiving pada saat penerimaan barang dan upaya penyelesaiannya. Receiving mengalami beberapa masalah pada saat penerimaaan barang, yaitu perbedaan harga barang dan perbedaan standar kualitas barang. Pada dasarnya penerimaan barang berdasarkan purchase order ataupun daily market list dimana keduanya sudah tercantum nama, jumlah,spesifikasi atau standar dan harga barang, tetapi kadang sering kali terjadi perbedaan harga antara yang tertera pada invoice dengan yang tertera pada purchase order ataupun daily market list. Hal ini juga daapat menyebakan terjadinya masalah dan menghambat pekerjaan receiving. Contohnya yaitu berupa harga ayam, harga ayam perkilo yang tertera pada daily market list untuk hari itu juga adalah sebesar $25.000,00$ sedangkan pada invoice sebesar $25.500,00$ perkilo.

Meskipun pada dasarnya receiving tidak ada hubungannya dengan masalah harga, tetapi disini receiving dituntut untuk menerima barang sesuai dengan apa yang tertera pada daily market list, baik itu harga, jumlah, dan spesifikasi ( standar). Receiving akan segera bertanya kepada purchasing tentang perbedaan harga tersebut. Nantinya purchasinglah yang akan menyelesaikan perbedaan harga tersebut dengan supplier. Perbedaan harga ini dapat terjadi kerena adanya miss comunication saat pemesanan barang antara purchasing dengan vendor yaitu vendor lupa menginformasikan atas kenaikan harga ayam kepada purchasing atau purchasing lupa mengganti harga terbaru pada saat pemesanan barang, atau bisa juga antara vendor dengan bagian administrasinya. Dalam hal ini diharapkan purchasing agar lebih memperhatikan kesepakatan harga sehingga tidak menghambat pekerjaan satu sama lain.

Sedangkan untuk masalah kualitas barang, hotel telah menetapkan standar yang diberlakukan dan dibuat oleh Archipelago International Hotel Resorts \& Residences contohnya berupa,

Nama buah : Salak

Spesifikasi : Tidak busuk, berwarna cerah, 1 $\mathrm{kg}$ isi $10-12$ biji

Nama buah : Lemon

Spesifikasi : Segar bersih, berwara kuning cerah, tidak busuk, $1 \mathrm{~kg}$ isi 3 biji.

Nama : melon rock

Spesifikasi : Tidak busuk, berwarana hijau segar, berat 1 buah minamal $1,25 \mathrm{~kg}$

Nama sayuran : baby phakcoy 
Spesifikasi : kecil, berwarna hijau segar, tidak busuk, bersih

Perbedaan kualitas yang sering terjadi yaitu berupa kedatangan baby phakcoy yang berbeda ukuran, ukurannya sedikit lebih besar dari standar yang ditetapkan dan melanggar kontrak yang telah disepakati sebelumnya. Bedanya jenis phakcoy dengan baby phakcoy juga mempengaruhi harga beli. Harga phakcoy lebih murah dari pada harga baby phakcoy, ini disebabkan karena phakcoy sudah lebih tau dari pada baby phakcoy. Kedatangan phakcoy ini terjadi karena petani telat memanen sayuran tersebut sehingga sudah tumbah lebih besar atau tua dari baby phakcoy ini karena minimnya permintaan dari pasar. Untuk hal ini biasanya chef masih memberikan toleransi kepada supplier karena faktor kebutuhan dan stock dipasaran juga memang besar-besar. Tetapi bukan berarti supplier tidak mendapat teguran, mereka tetap ditegur untuk menghindari kesalahan yang sama, purchasing harus lebih tegas lagi mengenai standar yang telah dibuat oleh pihak hotel.

Untuk dapat menjaga standar kualitas yang telah ditetapkan, purchasing diharapkan mampu berkomunikasi dan menjalin hubungan yang baik dengan supplier hal ini tentunya akan membawa keuntungan satu sama lain.

Dari analisa diatas, penulis menganalisa bahwa terjadinya perbedaan harga ini menjadi salah satu kendala bagi receiving saat menerima barang dan saat pembuatan laporan. Perbedaan harga ini terjadi karena miss comunication antara purchasing dengan vendor atau kurang teliti saat menginput harga baru. Sedangkan untuk kualitas, penulis menganalisa ini terjadi karena kurang tegasnya sikap yang diambil oleh purchasing terhadap vendor sehingga kualitas barang dapat menurun. Kedua hal diatas merupakan kendala yang harus ditegaskan.

Menurut analisa penulis, untuk mengatasi kedua kendala tersebut perlu adanya tindakan yang tegas. Harus mampu bekerja sesuai dengan standar yang telah ditetapkan, ketelitian dalam bekerja, serta mampu bekerja sama dengan vendor agar tidak merubah kualitas yang ditetapan seperti pada awal perjanjian.

\subsection{Kesimpulan Dan Saran}

\subsubsection{Kesimpulan}

Setelah melakukan penelitian dan interview dengan $\mathrm{Bu}$ Heny Purwaningsih selaku receiving staff di Grand Aston Hotel Yogyakarta, maka dapat ditarik kesimpulan :
1. Pentingnya Komunikasi Receiving Dengan Purchasing

a. Komunikasi antara receiving dan purchasing di Grand Aston Hotel Yogyakarta kurang berjalan dengan baik.

b. Kurangnya komunikasi yang baik menjadi salah satu kendala dalam pelaksanaan kerja dan akan berpengaruh terhadap hasil kerja yang dicapai.

2. Upaya Receiving Untuk Meminimalisir Terjadinya Kesalahan Pada Saat Penerimaan Barang

a. Memeriksa atau mengecek lembar pesanan dari purchasing sebelum menerima barang untuk memastikan sudah tidak ada pertanyaan mengenai barang yang akan diterima.

b. Mengecek barang yang datang sedetail dan seteliti mungkin, baik itu mengenai merk, kondisi barang, tanggal kadaluarsa, maupun spesifikasi barang yang diterima.

c. Memastikan barang yang diterima sesuai dengan pesanan dan sesuai dengan yang tertera pada invoice.

d. Selalu menjalin komunikasi dengan purchasing dan juga dengan department yang bersangkutan.

\subsubsection{Saran}

Saran yang dikemukakan oleh penulis dalam penellitian ini adalah sebagai berikut :

1. Perlu adanya kesadaran team work dan rasa saling memiliki baik purchasing maupun receiving, sehingga menumbuhkan rasa saling bertanggung jawab pada tugasnya masing-masing.

2. Harus mampu menjalin komunikasi yang baik antarapurchasing, receiving danstoresehingga hasil pekerjaan yang dicapai akan memuaskan dan tidak merugikan satu sama lain. Serta terhindar dari miss comunication yang tidak diinginkan di Grand Aston Hotel Yogyakarta.

3. Melakukan evaluasi kerja untuk mengetahui kendala yang dirasakan selama bekerja dan mencari solusi yang tepat untuk menangani kendala tersebut.

\section{Daftar Pustaka}

[1] Assauri, S. (2008), Penjelasan Tentang Purchasing.

[http://arripple.blogspot.co.id/2016/04/peng ertian-purchasing-menurut-para-ahl.html]. [11 Januari 2017]

[2] Bartono, (2005). Penjelasan Tentang Receiving.[http://cinkeynaara.blogspot.com /2011/11/prosedur.penerimaan-barang-direceiving.html].[07 November 2016]. 
[3] Depkes RI. (1994). Pedoman Pengelolaan dan Penyehatan Makanan Warung Sekolah, Jakarta.

[4] Dewi, YS. (2008). Higiene dan Sanitasi Pengelolaan Makanan pada Sentra Pedagang Makanan Jajanan Kesawan Square dan Pagaruyung.(Skripsi). FKM USU, Medan.

[5] Dwiloka B, and Rati Riana (2005), Tehnik Menulis Karya IImiah, Jakarta, PT Rineka Cipta.

[6] Gerson, Richard. F. (2004). Mengukur Kepuasan Pelanggan, Jakarta: PPM.

[7] Keputusan Menteri Parpostel no Km 94/HK103/MPPT 1987, Penjelasan Tentang Hotel. [http://www.mandalabhakti.ac.id/news_1_P engantar-Perhotelan--Definisi-HotelKarakteristik-Jenis-dan-Klasifikasi-Hotel.html]. [07 November 2016]
[8] Kotler, Philip. (2005). Manajemen Pemasaran, Edisi 11 jilid 1 dan 2 Pemasaran, Jakarta: PT. Indeks, Jakarta.

[9] Prabu.(2008). HigienedanSanitasiMakanan ,Jakarta.[Online].[http://www.landasanteori. com/2015/08/pengertian-higiene-sanitasimakanan.html]. [02 Januari 207]

[10]Tjiptono, Fandy \&Diana, Anastasia. (2003). Total Quality Management, Yogyakarta

[11]Arief, Muhtosim.(2007).Pemasaran Jasa dan Kualitas Pelayanan.Malang: Banyumedia Publishing.

[12] Tjiptono, Fandy. (2005). Prinsip-Prinsip Total Quality Service, Yogyakarta Sinambela, Lijan Poltak. (2010). Reformasi Pelayanan Publik, Jakarta: PT. Bumi Aksara. 